\title{
THE APPLICATION OF THE CHARTER OF FUNDAMENTAL RIGHTS OF THE EU IN POLAND
}

\author{
AGNIESZKA KASTELIK-SMAZA
}

\begin{abstract}
:
The paper aims at summarizing the experience in application of the Charter of Fundamental Rights of the EU by Polish courts. From the perspective of the Polish Constitutional Court EU law, including the Charter, has a universally binding character on Poland and it has priority over national law with a statutory and subordinate status, but not over the Constitution. The scope of protection guaranteed by the Charter is generally consistent with that provided for in the Constitution. Due to the fact that Poland has acceded to the British and Polish Protocol, the binding force and scope of applicability of the Charter are the subject of controversy in doctrine and case law. Nevertheless, the Polish Constitutional Court as well as common and administrative courts generally do not question the validity of the Charter, referring in different ways to its provisions in their rulings. The Charter is generally applied not as the main basis for the ruling, but as an additional element justifying the position adopted on the basis of Polish law. The Polish Constitution and the Convention for the Protection of Human Rights and Fundamental Freedoms are more likely to be chosen by the parties and by the courts as sources of fundamental rights invoked in the proceedings than the Charter. References to the Charter either by parties to the proceedings or courts themselves are often inadequate due to the lack of fulfilment of the conditions specified in Article 51 (1) of the Charter. In several cases invoking the provisions of the Charter outside the scope of application of EU law led to inadmissibility of preliminary references based on the Charter addressed to the CJEU by Polish courts.
\end{abstract}

Keywords: Charter of Fundamental Rights of the EU; Poland; constitution; constitutional court; preliminary references

Klíčová slova: Listina základních práv EU; Polsko; ústava; ústavní soud; řízení o předběžných otázkách

DOI: $10.14712 / 23366478.2018 .37$

\section{CHARTER AS A SOURCE OF LAW IN POLAND}

According to Article 87 of the Polish Constitution the sources of universally binding law of the Republic of Poland are: the Constitution, statutes, ratified international agreements, and regulations. The Constitution does not refer directly to EU law. The constitutional basis for the applicability of EU law in Poland, including the 
Charter of Fundamental Rights of the European Union (Charter), is Article 91 of the Constitution which provides:

"1. After promulgation thereof in the Journal of Laws of the Republic of Poland (Dziennik Ustaw), a ratified international agreement shall constitute part of the domestic legal order and shall be applied directly, unless its application depends on the enactment of a statute.

2. An international agreement ratified upon prior consent granted by statute shall have precedence over statutes if such an agreement cannot be reconciled with the provisions of such statutes.

3. If an agreement, ratified by the Republic of Poland, establishing an international organization so provides, the laws established by it shall be applied directly and have precedence in the event of a conflict of laws."1

Pursuant to the aforementioned provision, EU law, both primary and secondary, has a universally binding character on Poland and it has priority over national law with a statutory and subordinate status. However, Article 8 of the Constitution provides that the Constitution is the supreme law of the Republic of Poland. The Constitutional Court (Pl. Trybunał Konstytucyjny, CC) has confirmed in its case law that in Poland the Constitution has the primacy of binding force and application and therefore EU law has no priority over the Constitution. ${ }^{2}$

In this context, it should be noted that the scope of protection guaranteed by the Charter is generally consistent with that provided for in the Constitution. Some rights are not explicitly provided, for example the right to human integrity (Article 3 of the Charter) or the prohibition of slavery (Article 5 of the Charter). However, they are still applicable in Poland, because they have been interpreted from the Constitution by the Constitutional Court, or as standards binding under international agreements. ${ }^{3}$ An interesting example of the law provided for in the Charter and not included in the Constitution is the right to good administration (Article 41 of the Charter). ${ }^{4}$ The Constitution in Article 7 provides that public authority bodies operate on the basis and within

1 The Constitution of the Republic of Poland of 2 April 1997 (Dziennik Ustaw No. 78, item 483, Constitution). English version available at: http://www.sejm.gov.pl/prawo/konst/angielski/kon1.htm (accessed 18 May 2018).

2 CC in the judgments on the Treaty of Accession of 11 May 2005, K 18/04, OTK-A 2005/5/49 and the Treaty of Lisbon of 24 November 2010, K 32/09, OTK-A 2010/9/108. See also KAWCZYŃSKA, M.: Kontrola zgodności z Konstytucją aktów unijnego prawa pochodnego w postępowaniach przed Trybunałem Konstytucyjnym. In DUDZIK, S. - PÓŁTORAK, N. (eds.): Prawo Unii Europejskiej a prawo konstytucyjne państw czlonkowskich. Warszawa: Wolters Kluwer, 2014, pp. 214-215.

3 WRÓBLEWSKI, M.: The legal value and implementation of the Charter of Fundamental Rights in Poland. In PALMISANO, G. (ed.): Making the EU Charter of Fundamental Rights a Living Instrument, Rome: Brill Publisher, 2014, pp. 324-325; BODNAR, A.: The Charter of Fundamental Rights: the diverse legal nature of the Charter's provisions and its effect on individuals, courts and legislators, In BARCZ, J. (ed.): Fundamental Rights Protection in the European Union, Warszawa: C.H. Beck, 2009, p. 164. More about relations between the Charter and Polish Constitution: WIERUSZEWSKI, R.: Provisions of the Charter of Fundamental Rights in the light of the 1997 Constitution of RP and international agreements which are binding upon Poland. In BARCZ J. (ed.), Fundamental Rights Protection ..., pp. 145-167.

4 PYZIAK-SZAFNICKA, M.: Karta Praw Podstawowych UE w orzecznictwie Trybunatu Konstytucyjnego. "Europejski Przegląd Sądowy". Warszawa: Wolters Kluwer, 2016, nr 8, pp. 21-22. 
the limits of the law, however, such an approach is interpreted rather as a principle (of legalism) and not a subjective right, which significantly limits the possibility of reference to Article 7 by individuals. ${ }^{5}$ Probably this lack of right to good administration in the Constitution contributes to the fact that Article 41 is one of the Charter's provisions most frequently referred to in Polish courts.

\section{BRITISH AND POLISH PROTOCOL}

Despite the fact that pursuant to Article 6 (1) of the Treaty on European Union (TEU) the Charter has the same legal value as the Treaties and therefore shall be applied as an international agreement in Poland, its binding force and scope of applicability are the subject of controversy in doctrine and case law. ${ }^{6}$

This is due to the fact that Poland has acceded to Protocol No. 30 on the application of the Charter of Fundamental Rights of the European Union to Poland and to the United Kingdom (the British and Polish Protocol or the Protocol). Article 1 of the Protocol provides:

"1. The Charter does not extend the ability of the Court of Justice of the European Union, or any court or tribunal of Poland or of the United Kingdom, to find that the laws, regulations or administrative provisions, practices or action of Poland or of the United Kingdom are inconsistent with the fundamental rights, freedoms and principles that it reaffirms.

2. In particular, and for the avoidance of doubt, nothing in Title IV of the Charter creates justiciable rights applicable to Poland or the United Kingdom except in so far as Poland or the United Kingdom has provided for such rights in its national law."

In connection with the above, the British and Polish Protocol has been perceived in some positions as an opt-out clause with a conclusion that the Charter does not apply to Poland at all. ${ }^{7}$ In the opinion of the others, the Protocol does not exclude the validity

5 According to CC case law, the principle expressed in Article 7 of the Constitution is not the basis of freedom or subjective rights, which excludes the indication of this provision as a standard for a constitutional complaint, see e.g. judgment of CC of 8 July 2002, SK 41/01, OTK-A 2002/4/51.

6 See e.g. BIERNAT, S.: Czy Karta Praw Podstawowych Unii Europejskiej obowiązuje w Polsce. In KARDAS, P. - SROKA T. - WRÓBEL W. (eds.): Państwo prawa i prawo karne. Księga Jubileuszowa Profesora Andrzeja Zolla, Vol. 1. Warszawa: Wolters Kluwer, 2012, pp. 59-77; PÓ£TORAK, N.: Zakres zwiazania Kartq Praw Podstawowych Unii Europejskiej. "Europejski Przegląd Sądowy". Warszawa: Wolters Kluwer, 2014, Vol. 9, p. 17; KOWALIK-BAŃCZYK, K.: Konsekwencje przyjęcia protokołu polsko-brytyjskiego dotyczącego stosowania Karty Praw Podstawowych. In WRÓBEL, A. (ed.): Karta Praw Podstawowych w europejskim i krajowym porzadku prawnym. Warszawa: Wolters Kluwer, 2009, pp. 131-150; KOWALIK-BANCZYK, K.: Protokół w sprawie stosowania Karty Praw Podstawowych Unii Europejskiej do Polski i Zjednoczonego Królestwa. In WRÓBEL, A. (ed.): Karta Praw Podstawowych Unii Europejskiej. Komentarz. Warszawa: Legalis, 2013.

7 Regional Administrative Court in Warsaw, IV SA/Wa 1968/09, Central Base of Case Law of Administrative Courts available at http://orzeczenia.nsa.gov.p1/ (accessed 30 May 2018, CBOSA); PÓŁTORAK, N.: National Report: Poland. In BURGORGUE-LARSEN, L. (ed.): La Charte des droits fondamentaux de l'Union européenne saisie par les juges en Europe / The EU Charter of Fundamental Rights as apprehended by National Judges. Paris: Pedone (Col. Cahiers européens, no 10), 2017, p. 572. 
of the Charter in Poland, but limits its normative nature and may lead to inefficiency. ${ }^{8}$ According to the third, dominant approach, the Protocol is of minor importance and only applies in the scope of clarification and interpretation of the provisions of the Charter. ${ }^{9}$ In the context of the last position, it is also indicated that the decision to accede to the Protocol had a "symbolic" meaning for the Polish government and resulted from objections to the possible consequences of adopting the Charter on moral issues (provisions in the fields of family law, abortion, LGBT rights, ${ }^{10}$ etc.).

In the judgment in N.S. ${ }^{11}$ the Court of Justice of the EU (CJEU) ruled that the Protocol does not undermine the application of the Charter to the United Kingdom or Poland, and that:

"Article 1(1) of Protocol (No 30) explains Article 51 of the Charter with regard to the scope thereof and does not intend to exempt the Republic of Poland or the United Kingdom from the obligation to comply with the provisions of the Charter or to prevent a court of one of those Member States from ensuring compliance with those provisions."

Despite such a clear position expressed by the CJEU, it cannot be concluded that doubts about the impact of the British and Polish Protocol on the validity of the Charter in Poland have been finally settled ${ }^{12}$. In the recently issued judgment of 12 July 2017 the Polish Supreme Court (Pl. Sąd Najwyższy), stating that the alleged violation of Art. 30 of the Charter had been unfounded, argues: "Poland has signed Protocol No. 3042,13 which limits the scope of the Charter of Fundamental Rights". It also cites the provisions of the Protocol and literature indicating the limited significance of the Charter for Poland. It notes that this limitation was undermined in the judgment of the CJEU in the N.S. case, however, it concludes that, therefore, the Charter should "at least affect the process of interpretation of both EU law and Polish law by Polish courts". ${ }^{14}$ Thus, it still ascribes to the Charter only the role of an interpretive guide and not of an independent source of rights which individuals may refer to before Polish courts.

\footnotetext{
8 Opinia z dnia 25 lutego 2008 r. w sprawie skutków prawnych Karty Praw Podstawowych (RL-0303-8/08). "Przegląd Legislacyjny". Warszawa: Wolters Kluwer, 2008, Vol. 2, pp. 134-139, in which the Legislative Council stated that the Protocol made it impossible for the individuals to refer to the Charter in order to find Polish law incompatible with the Charter, to refer questions to the CJEU for that purpose or the European Commission's directing of complaints against Poland to the CJEU for infringement of the Charter.

9 Opinia dotyczaca skutku prawnego Protokolu w sprawie stosowania Karty Praw Podstawowych Unii Europejskiej w stosunku do Polski i Zjednoczonego Królestwa, Warszawa, 21 May 2008, http://rada legislacyjna.gov.pl/dokumenty/opinia-z-17-marca-2008-r-w-sprawie-skutkow-prawnych-karty-praw -podstawowych (accessed 31 May 2018).

10 Odpowiedź sekretarza stanu w Ministerstwie Spraw Zagranicznych - z upoważnienia Prezesa Rady Ministrów - na zapytanie nr 18706 w sprawie zastrzeżén do Karty Praw Podstawowych. Warszawa, 12 July 2013, http://www.sejm.gov.pl/sejm7.nsf/InterpelacjaTresc.xsp?key=6CD471D2 (accessed 31 May 2018).

11 C-411/10 and C-493/10 N.S., ECLI:EU:C:2011:865. A similar position was expressed by the Advocate General Juliane Kokott in the opinion of 15 December 2011 in the case C-489/10 Bonda, ECLI:EU:C:2011:845, who stated that the Protocol did not signify an opt-out from the Charter and served only as a guide for interpretation.

12 See more on this topic WRÓBLEWSKI, M.: The legal value ..., pp. 314-324.

13 Direct quotation, wrong number of the Protocol in the judgment.

14 Judgment of the Supreme Court of 12 July 2017, II PK 199/16, LEX No. 2338033.
} 
It must be admitted that the above-mentioned position of the Supreme Court is unusual in the newer case law. If there are any references to the Protocol, they usually come together with the judgment of the CJEU in the N.S. case. ${ }^{15}$ As a rule, however, the courts remain silent on the Protocol and do not question the validity of the Charter in Poland.

\section{THE CHARTER IN THE JURISPRUDENCE OF THE CONSTITUTIONAL COURT}

Before the entry into force of the Treaty of Lisbon, the Constitutional Court refused to rule on the basis of the provisions of the Charter, arguing that it was not a ratified international agreement and had no binding force. ${ }^{16}$ The situation has changed in the current legal state. The Polish Constitutional Court has not yet commented on the significance of the British and Polish Protocol, but it does not question the validity of the Charter in Poland, referring in different ways to its provisions in its rulings. ${ }^{17}$ At the same time, it underlines the common axiology of Polish law and legal orders of other countries, and the convergence of constitutional standards with the rights and freedoms set out in the Charter. ${ }^{18}$

The provisions of the Charter may be considered both an object and a standard of control in proceedings before the Constitutional Court.

In the first case, the legal basis for constitutional control of the Charter would be Article 188 (1) of the Constitution, which confers upon the Constitutional Court, among others, the competence to adjudicate on the conformity of international agreements

15 See e.g. the judgment of the District Court in Częstochowa of 18.03.2016, IV U 1470/12, LEX No. 2132656, in which the court additionally referred to the multicentric model of law enforcement, indicating that the judge was not bound by the law in the case of its collision with the Constitution and fundamental rights of the Union. "A norm contrary to Community law or a Constitution does not have to be removed from the system through a formal derogation, it may be omitted by the court. (...) In the Court's view, the principle of effective judicial protection provides the basis for assuming that whenever national rules (or the practice of applying the law) could prevent the protection of EU fundamental rights, the national court, in case of ineffective interpretation of national provisions, should refuse to apply them on the basis of Article 4 (3) TEU or create by means of interpretation a ruling that will protect the rule of law".

16 See e.g. order of CC of 27 September 2005, Tw 26/05, OTK-B 2005/5/182; PÓŁTORAK, N.: National Report ..., p. 574.

17 E.g. in the judgment of 14 December 2017, K 17/14, OTK-A 2018/4, CC held that in addition to Article 50 of the Constitution the respect for home was also guaranteed by the EU law, including Article 7 of the Charter. Binding effect of the Charter as an international agreement in connection with the principle nullum crimen, nulla poena sine lege poenali anteriori was emphasized by CC in the judgment of 12 March 2014, P 27/13, OTK-A 2014/3/30.

18 Likewise, among others in the judgment of 16 November 2011, SK 45/09, OTK-A 2011/9/97, in which the $\mathrm{CC}$ recognized its competence to examine the conformity of secondary EU law with the Constitution. In the rational of the judgment, it also referred to Article 47 of the Charter as an argument in favour of the compatibility of the examined provision of EU law with the constitutional right to a court. The object of control was Article 41 second sentence of Council Regulation (EC) No. 44/2001 of 22 December 2000 on jurisdiction and recognition of court judgments and their enforcement in civil and commercial matters (OJ L 12, 16 January 2001 p. 1, as amended). More on this topic DUDZIK, S. - PÓŁTORAK, N., The Court of the Last Word. Competences of the Polish Constitutional Tribunal in the Review of European Union Law. "Yearbook of Polish European Studies", Warszawa: CE UW, 2012, Vol. 15, pp. 225-258. 
with the Constitution. Due to the aforementioned Article 8, granting the primacy to the Polish Constitution, as well as the established case law of the Constitutional Court on this subject, a possible conflict between the standard of protection of fundamental rights guaranteed in the Constitution with the one in the Charter would have to lead to the refusal to apply the Charter in Poland in the scope of conflict. ${ }^{19}$

As far as the Charter as a standard of constitutional review is concerned, the Constitutional Court has clearly stated that in Poland the Charter cannot be set up as a standard of control under the constitutional complaint, which is the only remedy enabling individuals to have direct access to the Constitutional Court. ${ }^{20}$ According to art. 79 (1) of the Constitution:

"In accordance with principles specified by statute, everyone whose constitutional freedoms or rights have been infringed, shall have the right to appeal to the Constitutional Court for its judgment on the conformity to the Constitution of a statute or another normative act upon which basis a court or organ of public administration has made a final decision on his freedoms or rights or on his obligations specified in the Constitution."

Consequently, an individual may only invoke freedoms or rights specified in the Constitution and not in other legal acts such as the Charter or the Convention for the Protection of Human Rights and Fundamental Freedoms (ECHR). ${ }^{21}$ The Charter may be referred to subsidiarily, if the rights specified therein coincide with those guaranteed in the Constitution.

It seems, however, that the Charter may be a standard of control under other proceedings before the Constitutional Court: in response to preliminary questions from ordinary courts or in the scope of abstract constitutional review on the request of public authorities.

There is currently no judgment of the Constitutional Court in which a direct assessment of the conformity of national law with the Charter has been made, despite various referrals to the Charter by national courts ${ }^{22}$ and other applicants among which the Polish

19 The provisions of Polish law in the event of their non-compliance with the Constitution lose their binding force. In the case of EU law such a result would be impossible. Conformity between the Constitution and the Charter could be reached by amending the Constitution. Such a situation has already occurred in relation to EU law in order to remove the conflict between Article 55 (1) of the Constitution, prohibiting the extradition of a Polish citizen, and the provisions of the Council Framework Decision of 13 June 2002 on the European arrest warrant and the surrender procedures between Member States (OJ L 190, 18 July 2002, pp. 1-20). However, amendment of the Constitution seems unlikely in the case of a difference in standards for the protection of fundamental rights.

20 More on this topic KOWALIK-BAŃCZYK, K. - WRÓBLEWSKI, M.: Application of the Charter of Fundamental Rights by Polish Courts and the Jurisprudence of the Polish Constitutional Tribunal. "Yearbook of Polish European Studies". Warszawa: CE UW, 2015, Vol. 18, pp. 252-263.

21 See. WRÓBLEWSKI, M., Karta Praw Podstawowych UE w orzecznictwie Trybunału Konstytucyjnego - stan obecny i perspektywy. "Europejski Przegląd Sądowy". Warszawa: Wolters Kluwer, 2015, Vol. 10, p. 21. Orders of the CC of 5 May 2015, Ts 349/14, OTK-B 2015/5/497 and Ts 350/14, OTK-B 2015/5/499 and of 6 December 2017, Ts 247/16, OTK-B 2018/13.

22 Provisions of the Charter were invoked in the case P 19/14 by the Court of Appeal in Gdańsk which raised doubts whether Article $85 \S 4$ of the Criminal Code, prohibiting to include convictions handed down in other EU Member States in a joint judgment, complied with Article 32 (1) of the Constitution and Article 20 
Ombudsman is the most active (the Ombudsman). It should be emphasized that the Ombudsman indicates the Charter as a standard of control while demonstrating that EU law is applicable in a given case. ${ }^{23}$ This diligence is often lacking for other applicants who refer to the provisions of the Charter mainly to strengthen argumentation based on other provisions, often in matters that are outside the scope of application of EU law.

The Constitutional Court happens to refer to the provisions of EU law and European standards of human rights protection, including those specified in the Charter, also ex officio, even if these provisions have not been invoked as a standard of constitutional review. ${ }^{24}$ Interestingly enough, such referrals also take place in the proceedings initiated by lodging a constitutional complaint. ${ }^{25}$

\section{APPLICATION OF THE CHARTER BY POLISH COMMON AND ADMINISTRATIVE COURTS}

The Polish common and administrative courts generally apply the Charter not as the main basis for the ruling, but as an additional element justifying the position adopted on the basis of Polish law. ${ }^{26}$ The most frequently invoked provisions of

\footnotetext{
of the Charter. In this case, the Sejm (Polish lower chamber of Parliament) expressed its position on the inadmissibility of adjudicating on the basis of the Charter, because it claimed the Charter not to be a ratified international agreement. Finally, by the decision of 15 December 2016, OTK-A 2016/95, the Constitutional Court discontinued the proceedings for procedural reasons, without commenting either on the admissibility of the Charter's application or on the compliance of the reviewed provision with the Charter.

23 E.g. in the case K 32/14 the Ombudsman claimed that the provisions prohibiting the so-called ritual slaughter of animals were incompatible among others with Article 10 (1) of the Charter (freedom of thought, conscience and religion). Also in this case, the Constitutional Court did not issue a substantive decision, because the challenged provision lost its binding force as a result of an earlier $\mathrm{CC}$ judgment (Order of the CC of 3 November 2015, K 32/14, OTK-A 2015/10/166). The Constitutional Court pointed out in its order to discontinue the proceedings that Article 10 (1) of the Charter was not an adequate standard of control in this case and that Article 10 (2) should have been invoked instead (right to refuse to act contrary to conscience). In this way, the $\mathrm{CC}$ admitted indirectly that the rights and freedoms included in the Charter may constitute a standard of control in proceedings before the Constitutional Court.

24 In the judgment of 14 December 2017, K 17/14, OTK-A 2018/4, CC, while examining the compliance of provisions regulating the search of persons, carrying out a personal check and searching vehicles by public officials, pointed out that "the inviolability of the home is also guaranteed by the European Union law. According to Article 7 of the Charter of Fundamental Rights of the European Union (OJ of the EU C 303 of 14 December 2007, p. 1, as amended), everyone has the right to respect for private and family life, home and communication". In the judgment of 21 October 2014, P 50/13, OTK-A 2014/9/103, the CC, assessing the conformity with the Constitution of imposing an administrative and criminal sanction for the same act in the light of the ne bis in idem principle, referred in the grounds to Article 50 of the Charter. The reference to the Charter was also made in a dissenting opinion by Judge Sławomira Wronkowska-Jaśkiewicz to the judgment of the Constitutional Court of 16 March 2017, Kp 1/17, OTK-A 2017/28, in which the Constitutional Court assessed compliance with the Constitution of the Act of 13 December 2016 on the amendment to the Act - Law on Assemblies. See also the dissenting opinion of Judge Mirosław Granat on the rational of the judgment of the Constitutional Court of 31 July 2015, Ref. act K 41/12.

25 As mentioned above, the claimant cannot invoke the provisions of the Charter as a standard of control in this proceeding, nevertheless, the Constitutional Court itself applies the Charter ex officio in the rational of its judgments as support for its own arguments, such as Article 47 of the Charter in the judgment of 20 December 2017, SK 37/15, OTK-A 2017/90.

26 PÓŁTORAK N.: National Report ..., p. 578.
} 
the Charter are Article 41 (right to good administration) ${ }^{27}$ and Article 47 (right to an effective remedy and fair trial). ${ }^{28}$ They are usually accompanied by a reference to the provisions of international law, especially the ECHR. ${ }^{29}$

References to the Charter either by parties to the proceedings or courts themselves are often inadequate due to the lack of fulfilment of the conditions specified in Article 51 (1) of the Charter. It should be admitted, however, that awareness in this area is increasing and courts are more likely to investigate whether the provisions of EU law apply in a given case as well as to support their position with the relevant jurisprudence of the CJEU. ${ }^{30}$

It is worth noting that Polish courts apply the Charter not only in the case of reference thereto by the parties to the proceedings, but also ex officio, usually to enhance their argumentation in the rational of the decision. ${ }^{31}$

27 E.g. in the judgment of 15 March 2018, I OSK 2305/17, CBOSA, the Supreme Administrative Court stated that "the right to hear an administrative matter within reasonable time as part of the right to good administration is also one of the fundamental rights in the legal order of the European Union (see Article 41 (1) of the Charter of Fundamental Rights - OJ EU C.2007.303.1). Although the provision of the Charter refers directly to the EU authorities, in the light of the case-law of the Court of Justice and the Supreme Administrative Court, it is also binding on the Member States as a general principle of EU law".

28 E.g. the Supreme Administrative Court's resolution of 7 judges of 16 October 2017, I FPS 1/17, CBOSA, in which the Supreme Administrative Court ruled that the CJEU ruling issued under the preliminary reference procedure constitutes the basis for the resumption of court-administrative proceedings, having invoked, inter alia, the right to court formulated in Article 47 KPP. In the opinion of the Supreme Administrative Court "due to limited access of individuals to the EU Courts and entrusting effective legal protection to Member States, this provision gives first and foremost the right to access to national courts in order to pursue claims resulting from EU law".

29 E.g. in the judgment of 2 June 2017, III UK 147/16, LEX No. 2296861, the Supreme Court held that in addition to Article 67 of the Polish Constitution, "European Social Charter drafted in Turin of 18.10.1961 (Dz.U. of 1999 No. 8, item 67) obliges to establish and maintain a social security system at a satisfactory level, at least the level necessary for the ratification of the International Labour Organization Convention (No. 102) concerning Minimum Standards of Social Security. It is also aimed at soliciting a gradual improvement in the level of the social security system. This guideline corresponds with the provisions of Article 34 of the Charter of Fundamental Rights of the EU (O.J. EU C of 14.12.2007), as well as it complies with the standard of the Convention on the Protection of Human Rights and Fundamental Freedoms (...)".

30 See the aforementioned resolution of the Supreme Administrative Court, I FPS 1/17; judgment of the Supreme Administrative Court of 6 October 2015, II GNP 7/15, CBOSA; judgment of the Supreme Administrative Court of 19 December 2017, II OSK 657/16, CBOSA; judgment of the Supreme Administrative Court of 27 April 2017, II FNP 3/17 CBOSA; order of the Supreme Administrative Court of 17 August 2017, II ONP 2/17, CBOSA; judgment of the Supreme Court of 16 March 2016, IV CSK 270/15, OSNC $2017 / 1 / 12$.

31 In the judgment of 8 June 2017, II PK 177/16, LEX nr 2321879, the Supreme Court invoked the principle of equality before the law (Article 20 of the Charter) and non-discrimination (Article 21 of the Charter) to justify the interpretation adopted as to how to prove political discrimination in the employment relationship. Moreover, in the judgment of 8 September 2017, II CSK 771/16, LEX No. 2372555, the Supreme Court referred to the right to liberty of person under Article 6 of the Charter while stating the unlawfulness of execution of a sentence of imprisonment in a dimension larger than that resulting from a final conviction. In this case, a period of actual deprivation of liberty abroad in connection with the issuance of a European arrest warrant was not counted towards the total period of imprisonment. 


\section{PRELIMINARY REFERENCES OF THE POLISH COURTS BASED ON THE CHARTER}

By the end of 2017 the Polish courts had referred ten questions for preliminary rulings, in which the Charter of Fundamental Rights of the EU had been invoked.

In four of them, the CJEU found itself obviously incompetent to issue a ruling. This was due to the fact that the referring courts in their applications did not show that the subject of the main proceedings was related to the interpretation or application of a provision of EU law other than the provisions contained in the Charter, and thus that the conditions provided for in Article 51 (1) had been met. ${ }^{32}$ The Court referred to its settled case law that "the fundamental rights guaranteed in the legal order of the European Union are applicable in all situations governed by European Union law, but not outside such situations. In this respect the Court has (...) no power to examine the compatibility with the Charter of national legislation lying outside the scope of European Union law"33. It is for the national court to demonstrate that national provisions fall within the scope of EU law and to provide explanations for assessing the compatibility of these provisions with fundamental rights.

In the case C-397/14 Polkomtel the Supreme Court referred questions about the scope of admissible interference by national regulatory authorities in the activities of telecommunications operators in the light of the EU directives applicable to electronic communications services. In its questions it raised doubts as to the compatibility of such interference with the freedom to conduct a business established in Article 16 of the Charter. It also pointed to the possibility of a collision between the aforementioned freedom and the principle of consumer protection expressed in Article 38 of the Charter. The CJEU issued a preliminary ruling in this case, however, not based on the provisions

32 Under the settled case law the CJEU has no jurisdiction to issue a preliminary ruling in such cases, see C617/10 Akerberg Fransson, ECLI:EU:C:2013:105.

33 C-282/14 Stylinart, ECLI:EU:C:2014:2486. In this case the question for a preliminary ruling of the District Court in Rzeszów concerned the compliance of national legislation related to the expropriation of goods with Article 16 and 17 of the Charter. Similarly, in C-28/14 Pańczyk, ECLI:EU:C:2014:2003 which concerned the compliance with the national provisions of the decision on recalculation of the pension of a police officer and in which the District Court in Częstochowa asked about the compliance of the law on retirement provision of officers with Article 1, 17, 20, 21, and 47 of the Charter in connection with Article 2 TEU, Article 4 (3) TEU and Article 6 TEU. In C-50/16 Halina Grodecka, ECLI:EU:C:2016:406 the District Court in Konin had doubts whether Article 2 TFEU and 8 TFEU, Article 1 of Protocol No. 1, Article 14 ECHR and Article 17 (1) of the Charter preclude national provisions limiting the transfer on succession of agricultural holdings where the inheritor does not satisfy certain substantive criteria laid down by the law relating to its ability to manage such a holding. In addition to the lack of connection with EU law, the CJEU pointed out that the facts of the main proceedings preceded the date of accession of the Republic of Poland to the European Union, i.e. 1 May 2004. In C-520/13 Urszula Leśniak-Jaworska, Matgorzata Gluchowska-Szmulewicz, ECLI:EU:C:2014:263 the District Court in Płock referred a question regarding the compatibility of the differentiation of employees' remuneration with Article 21 of the Charter and Article 1 and 2 of Directive 2000/78. The question did not meet the requirements set out in Article 267 TFEU, because the court did not provide sufficient explanation on the factual and legal background of the main proceedings and the reasons justifying the need to obtain an answer to the question referred for a preliminary ruling. 
of the Charter, as it assessed that the facts of the case concerned the period before the Charter's entry into force. ${ }^{34}$

Subsequently, the Supreme Court correctly formulated the questions referred in two other cases concerning electronic communications services: C-231/15 Petrotel and C-277/16 Polkomtel. In the first one the CJEU confirmed that Article 4(1) of Directive 2002/21/EC, which require the Member States to provide for effective appeal mechanisms, in conjunction with Article 47 of the Charter of Fundamental Rights of the European Union, is to be interpreted as meaning that a national court hearing an appeal against a decision of the national regulatory authority must be able to annul that decision with retroactive effect, if it finds that to be necessary in order to provide effective protection for the rights of the undertaking which has brought the appeal ${ }^{35}$. In the second one, the Supreme Court had doubts, whether Article 16 of the Charter precludes the possibility, for a national regulatory authority, to require an operator to update its prices on an annual basis and to submit them for periodic monitoring. According to the CJEU, the protection afforded by Article 16 of the Charter "covers the freedom to exercise an economic or commercial activity, freedom of contract and free competition. In addition, freedom of contract includes, in particular, the freedom to choose with whom to do business and the freedom to determine the price of a service. However, the freedom to conduct a business does not constitute an absolute prerogative, but must be viewed in relation to its function in society". For this reason, the CJEU decided that Article 16 of the Charter allows for the questioned interference, provided that the obligations imposed comply with the principle of proportionality. ${ }^{36}$

In the only case dealt with so far in the urgent procedure, C294/16 PPU JZ, the District Court for Łódź-Śródmieście in Łódź asked for an interpretation of Article 26(1) of Framework Decision 2002/584 in the light of the principle of proportionality in the application of penalties, as provided for in Article 49(3) of the Charter. The aforementioned Article imposes the obligation to deduct the period of detention arising from the execution of the European arrest warrant from the total period of detention which the person concerned would be required to serve in the issuing Member State. The referring court asked particularly whether the term 'detention' also covers measures consisting in the electronic monitoring of the place of residence of the person to whom the arrest warrant applies, in conjunction with a curfew. The CJEU, in the rational of the judgment, analysed the problem also in the context of the right to liberty and security of person guaranteed by Article 6 of the Charter as well as Article 5 of the ECHR, referring to the content of Article 52 (3) of the Charter. Finally, it came to the conclusion that these measures could not be classified as 'detention'. 37

Reference in the case C-403/16 El Hassani, made by the Polish Supreme Administrative Court, concerned interpretation of Article 32(3) of the Visa Code, read together with Article 47 of the Charter, particularly, if it requires the Member States to guarantee

34 C-397/14 Polkomtel, ECLI:EU:C:2016:256. The Charter entered into force on 1 December 2009, and the decision of the President of the Office of Electronic Communications was issued on 6 May 2009.

35 C-231/15 Petrotel, ECLI:EU:C:2016:769.

36 C-277/16 Polkomtel, ECLI:EU:C:2017:989.

37 C-294/16 PPU JZ, ECLI:EU:C:2016:610. 
an effective remedy (appeal) before a court of law against a decision refusing the issue of a visa. The CJEU confirmed the existence of such obligation on the basis of the invoked provision of the Charter. ${ }^{38}$ Following the CJEU judgment, the Supreme Administrative Court refused to apply Article 5 (4) of the Polish Law on proceedings before administrative courts, which excluded the possibility of examination of an appeal by an administrative court in this case. ${ }^{39}$ The consequence of such a decision should be the recognition of appeal against the decision refusing the issue of a visa.

The final question was addressed by the Supreme Court in the case C-617/17 Powszechny Zakład Ubezpieczeń na Życie and concerned the decision of the President of the Office of Competition and Consumer Protection which imposed two sanctions on the same entity for the same behaviour for partially overlapping periods: the first one for domestic infringement, and the second one for infringing the EU competition law. ${ }^{40}$ In this situation the Supreme Court requested interpretation of ne bis in idem principle having regard to Article 50 of the Charter. In this case there is also an interesting issue of the possible conflict with Article 4 of the Protocol 6 to the ECHR which provides for a more extensive protection than the Charter.

In all of the above cases, the referring courts invoked the provisions of the Charter in their questions for a preliminary ruling. In other cases, the Charter is not explicitly mentioned in the question, however, it appears in the motives of a preliminary reference when interpreting or assessing the validity of secondary legislation. ${ }^{41}$ In the latter way, the provisions of the Charter were applied in the first and, so far, only reference for a preliminary ruling addressed to the CJEU by the Polish Constitutional Court. ${ }^{42}$

It is worth noting that although the vast majority of questions referred from Poland originate from administrative courts, the Charter is invoked mainly in preliminary references of the Supreme Court and common courts. ${ }^{43}$

38 C-403/15 El Hassani, ECLI:EU:C:2017:960.

39 Order of the Supreme Administrative Court of 19 February 2018, II OSK 1346/16, CBOSA.

40 Not yet decided.

41 C-119/15 Biuro podróży „Partner”, ECLI:EU:C:2016:987; C-149/16, Halina Socha, not yet decided.

42 C-390/15 RPO, ECLI:EU:C:2017:174. In this case, the Ombudsman requested a review by the Constitutional Court of the provisions of the VAT Act, indicating also the possible incompatibility of the VAT directive with Article 20 of the Charter (equality before the law). The Constitutional Court referred a question to the CJEU regarding the validity of EU law. In a judgment of 7 March 2017 the CJEU held: "the analysis of the questions referred did not reveal any element that could affect the validity" of point 6 of Annex III to the VAT Directive or Article 98 (2) of that Directive in conjunction with point 6 of Annex III thereto. In this case there was no substantive decision, because the Ombudsman finally withdrew the application and the Constitutional Court decided to discontinue the proceedings (order of 17 May 2017, K 61/13, OTK-A 2017/38).

43 It should be noted that before publishing this paper the Supreme Court issued several decisions, in which it addressed to the CJEU questions for preliminary ruling based among others on Article 47 of the Charter. The Supreme Court raised doubts about compliance of the new Act on the Supreme Court (Dz.U. of 2018, item 5, as amended) which lowers the retirement age of judges with the rule of law and the principle of effective judicial protection arising therefrom - concerning independence and impartiality of courts and judges therein (see C-522/18, C-537/18 and C-585/18, not yet decided). The decision of 2 August 2018, III UZP 4/18 (CJEU C-522/18) had precedential character, because the Supreme Court suspended the application of several provisions of the questioned legal act until the CJEU issues the preliminary ruling in this case. 


\section{CONCLUSION}

Despite Polish accedence to the British and Polish Protocol, the Charter of Fundamental Rights of the European Union is applied in Poland by the parties to the proceedings as well as by courts, including Constitutional Court. The main problem seems to be the scope of applicability of the Charter under Article 51 (1). The lack of due diligence in this respect by applicants, claimants, or the courts themselves makes references to the Charter often inadequate and preliminary questions inadmissible. Nevertheless, it may be concluded that the awareness in this respect has been growing.

Still the Polish Constitution and secondly the Convention for the Protection of Human Rights and Fundamental Freedoms remain more popular sources of fundamental rights than the Charter, and their provisions are often invoked next to the Charter. This is not surprising as they have broader scope of applicability and may be invoked in cases not necessarily governed by European Union law.

It is worth noting that the Charter has also been applied in the infringement proceedings initiated by the European Commission against Poland in connection with the Law on the system of common courts ${ }^{44}$ and the Law on the Supreme Court. ${ }^{45}$ The Commission invoked Article 19 paragraph 1 TEU in conjunction with Article 47 of the Charter while pointing out that granting the Minister of Justice and in the second case the President of the Republic of Poland - discretion in making decisions regarding the extension of active mandate of judges who had reached retirement age would undermine the independence of Polish courts. Both cases will be determined under the expedited procedure.

Adwokat Agnieszka Kastelik-Smaza, Ph.D.

Member and lecturer of the Regional Bar Association in Bielsko-Biała, Poland agnieszka.kastelik-smaza@adwokatura.pl

44 C-192/18 European Commission v Republic of Poland, action brought on 15 March 2018, not yet decided.

45 C-619/18 European Commission v Republic of Poland, action brought on 2 October 2018, not yet decided. In this case the CJEU issued the order of 19 October 2018 under which Poland must immediately suspend the application of the provisions of national legislation relating to the lowering of the retirement age for Supreme Court judges (C-619/18 R). 